\title{
EXTRACELLULAR VESICLES PRODUCED BY MOUSE BREAST ADENOCARCINOMA 4T1 CELLS WITH UP- OR DOWN-REGULATION OF ADAPTOR PROTEIN RUK/CIN85 DIFFERENTIALLY MODULATE THE BIOLOGICAL PROPERTIES OF 4T1 WT CELLS
}

\author{
A. Yu. ZHYVOLOZHNYI ${ }^{1,2 ⿴}$, I. R. HORAK ${ }^{1}$, D. S. GERASCHENKO ${ }^{1}$, M. O. GOMOZKOVA ${ }^{3}$, \\ O. O. HUDKOVA' 1 , S. J. VAINIO ${ }^{2}$, A. A. SAMOYLENKO ${ }^{2}$, L. B. DROBOT \\ ${ }^{1}$ Palladin Institute of Biochemistry, National Academy of Sciences of Ukraine, Kyiv; \\ ${ }^{2}$ Faculty of Biochemistry and Molecular Medicine, University of Oulu, Finland; \\ ${ }^{3}$ Brigham Young University-Idaho, Rexburg, USA; \\ 凶e-mail:ppndl2@gmail.com
}

Received: 02 November 2021; Accepted: 12 November 2021

Extracellular vesicles (EVs) are secreted by most cell types under both physiological and pathological conditions and were proposed to be actively involved in intercellular communication. The mode of EVs action is dependent on their cargos composition. EVs play an important role in tumor initiation, recurrence, metastasis and therapeutic resistance. EVs marker proteins Alix and Tsg101 and cortactin are the binding partners of adaptor protein Ruk/CIN85. The present study aims to analyze the regulatory effects of EVs produced by $4 T 1$ cells with overexpression (RukUp) or down-regulation (RukDown) of adaptor protein Ruk/CIN85 on proliferation rate, migration and invasion activity of parental $4 T 1$ WT cells. EVs from conditioned medium of 4T1 RukUp or RukDown cells were isolated by differential centrifugation followed by further purification using Exo-spin ${ }^{\mathrm{TM}}$ kit (Cell Guidance Systems). The number and size of EVs were characterized by NTA (Malvern Panalytical NanoSight NM300) instrument. The content of marker proteins and Ruk/CIN85 in isolated EVs was analyzed by Western-blotting. The viability, migration and invasion activity of $4 T 1$ WT cells were studied using MTT-test, scratch-test and Boyden chamber assay, respectively. It was demonstrated for the first time that adaptor protein Ruk/CIN85 is a constitutive component of EVs produced by $4 T 1$ cells. It was also shown that EVs produced by $4 T 1$ cells with different levels of Ruk/CIN85 expression are characterized by a specific profile of the content of its multiple molecular forms. It turned out that the ability of EVs to modulate the proliferative activity, motility and invasiveness of 4T1 WT cells was tightly correlated with the biological properties of $4 T 1$ cells that produce EVs (highly aggressive 4T1 RukUp cells or weakly invasive 4T1 RukDown cells). Our data suggest that adaptor protein Ruk/CIN85 is not only a constitutive component of cargos composition of EVs produced by tumor cells but, depending on its content in EVs, plays an active role in the control of carcinogenesis.

Ke y wo r d s: carcinogenesis, breast cancer, extracellular vesicles, adaptor protein Ruk/CIN85, viability and migration of cell, invasion.

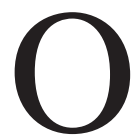
ver the past decade, it has been shown that membrane-coated extracellular vesicles (EVs) secreted by tumor cells play a fundamental role in carcinogenesis. By transporting cargo components (various proteins, nucleic acids, lipids, and metabolites) to neighboring tumor cells, including stromal cells in the microenvironment, EVs participate in intercellular communication that lead to modulation of intracellular signaling networks of target cells and reprogramming their transcriptome and metabolome status. In this way, EVs modulate tumor cells features such as immune sup-

(C) 2021 Zhyvolozhnyi A. Yu. et al. This is an open-access article distributed under the terms of the Creative Commons Attribution License, which permits unrestricted use, distribution, and reproduction in any medium, provided the original author and source are credited. 
pression, angiogenesis, drug resistance, migration and invasion as well as tumor growth and metastasis $[1,2]$. Data are accumulated that EVs' effects on carcinogenesis occur in a cell of origin dependent manner. This indicates that the treated cells acquire characteristics resembling the EVs cell of origin [3-5].

The main organizers of signaling networks are adaptor/scaffold proteins, which contain multiple domains and motifs involved in intermolecular interactions that allow them to function as molecular platforms in signal processing [6]. It was demonstrated early that high levels of SH3-containing adaptor protein Ruk/CIN85 in breast cancer cells were correlated with the degree of their malignancy and advanced tumor stage [7, 8]. Because EVs’ marker proteins Alix and Tsg101, involved in the formation of MVBs, as well as cortactin, which stimulates the secretion of EVs, are the binding partners of Ruk/ CIN85 [9-12], we hypothesized its role in the biogenesis of EVs and modulation of their biological activities. In order to better understand the mechanisms through which Ruk/CIN85 affects breast carcinogenesis, in this study we investigated the influence of EVs produced by murine breast adenocarcinoma 4T1 cells with stable overexpression or down-regulation of the adaptor protein on biological responses (viability, migration, and invasion) of parental 4T1 cells in vitro. 4T1 cells represent the surrogate model of human basal-like triple negative breast cancer cells, characterized by hybrid epithelial-mesenchymal phenotype $[13,14]$ associated with their plasticity.

\section{Materials and Methods}

Cell culture and transfection. Murine breast adenocarcinoma cells 4T1 cells (ATCC® CRL$2539^{\mathrm{TM}}$ ) were cultured in RPMI 1640 medium (Gibco, 21875034) supplemented with $10 \%$ fetal bovine serum (FBS) (Gibco, 26140079) with $100 \mathrm{U} / \mathrm{ml}$ penicillin and $100 \mu \mathrm{g} / \mathrm{ml}$ streptomycin in $5 \% \mathrm{CO}_{2}$ atmosphere at $37^{\circ} \mathrm{C} .1 \times 10^{6}$ cells per $10 \mathrm{~cm}$ dish (Greiner Cellstar, 664160) were plated for cell culturing. The sublines with stable overexpression and knock-down of full-length Ruk/CIN85 form have been described earlier [15].

EVs purification. Cultured 4T1 cells were kept until $80 \%$ of confluence in standard medium and $10 \mathrm{~cm}$ culture dishes. Then the medium was changed for the medium without FBS and kept for $24 \mathrm{~h}$ followed by medium collection. To remove debris, the collected medium was centrifuged at $3500 \mathrm{~g}$ for $15 \mathrm{~min}$. The obtained debris-free medium was con- centrated using Centricon Plus-70 filter units (Merck Millipore, cut-off 100k) for 15 to $30 \mathrm{~min}$. The concentrated medium was diluted with PBS to the total volume of $12 \mathrm{ml}$. Then samples were centrifuged at $100000 \mathrm{~g}, 4^{\circ} \mathrm{C}$ (Sorvall TH-641 rotor) for $6 \mathrm{~h}$. Obtained pellets were suspended in $200 \mathrm{mkl}$ PBS and further purified using Exo-spin ${ }^{\mathrm{TM}}$ kit (EXO3) according to the manufacturer's protocol.

NTA measurements. The EVs particles concentration and size ratio were measured by nanoparticle tracking analysis (NanoSight NM300, Malvern Panalytical). Before measurements, samples were diluted 1:100 in distilled water. Brownian motion of each sample was recorded eight times (60-sec videos) with camera level 14 and detection threshold 3. NTA software version 3.4 was used for data analysis.

Electron microscopy. Transmission electron microscopy (TEM) was used for samples analysis. Each EVs sample was fixed on a Formvar carbonated grid and stained with $2 \%$ uranyl acetate. Immuno-TEM was performed using anti-CD63 antibody (LAMP-3, MBL, Nagoya, Japan; 1:100 dilution).

Western blot analysis. The cell lysates were prepared by adding $2 \mathrm{ml}$ of RIPA buffer solution (Sigma-Aldrich R0278) with phosphatase (Roche 50892791001) and proteinase (Sigma P5726) inhibitors per one dish. After cell scratching, lysates were incubated for 20 min on shacking platform at $4^{\circ} \mathrm{C}$ followed by centrifugation at $10000 \mathrm{~g}$. EVs samples were lyzed in RIPA buffer (Cell Signaling Technology) with phosphatase inhibitors (Sigma-Aldrich) and protease inhibitors (cOmplete ${ }^{\mathrm{TM}}$ ULTRA Roche). Proteins were separated via 10\% SDS PAGE gel and transferred to the nitrocellulose membrane (Thermo Scientific ${ }^{\mathrm{TM}}$ 88018). The membranes were incubated overnight at $4^{\circ} \mathrm{C}$ with anti-Ruk/CIN85 C-terminal antibodies (1:3000) [16], and antibodies against EVs markers CD63 (sc-15363, 1:1000) and CD81 (sc-166029, 1:1000). The corresponding goat HRP-conjugated secondary antibodies (Invitrogen) at 1:5000 dilutions were applied. For the visualization of bound secondary antibodies, the Lumi-Light Western Blotting Substrate (Roche Diagnostics, 12015200001, Switzerland) was used.

Cell viability. Cells were seeded in 96-well plates $\left(1 \cdot 10^{3}\right.$ per well). After 24 hours, the culture medium was removed and the cells were treated with a medium containing EVs $\left(1 \cdot 10^{8}\right.$ per $\left.100 \mu \mathrm{l}\right)$ for 24 h. The commercially available MTT assay kit (Sigma-Aldrich) was used to estimate cell viability. At the end of experiment, MTT $(0.5 \mathrm{mg} / \mathrm{ml})$ was added 
to each well and after 120 min, the MTT solution was removed. The formazan crystals were diluted in $200 \mu 1$ of DMSO, and the absorbance of formazan was measured at $570 \mathrm{~nm}$.

Wound healing assay. 4T1 cells were plated onto 6-well dishes and grown to $90 \%$ confluence and serum-starved overnight. Then a wound with a width of $\sim 0.2 \mathrm{~mm}$ was scratched with a sterile 200$\mu \mathrm{l}$ pipette tip in the middle of the monolayer. Cells were then incubated with the new complete RPMI medium containing $1 \mu \mathrm{M}$ mitomycin C (Sigma-Aldrich), to eliminate effects of cellular proliferation on wounding, and EVs $\left(1 \cdot 10^{8}\right.$ per $\left.100 \mu \mathrm{l}\right)$. The wound closure was monitored by phase-contrast microscopy. Photoimages were taken at 0 and $24 \mathrm{~h}$ after cells scratching. Cell wound closure evaluation was done by WimScratch Wimasis Image Analysis (Wimasis $\mathrm{GmbH}$ ) as described in [7].

Transwell invasion assay. The cell invasion assay was done as described in [17] using 24-well inserts with $8 \mu \mathrm{m}$ pores (Greiner Bio-One). 1·10 cells were plated on the upper wells of chambers in the presence of $0.1 \%$ FBS. The bottom wells were filled with $10 \%$ FBS medium. After incubation for $24 \mathrm{~h}$ in the presence of EVs $\left(1 \cdot 10^{8}\right.$ per $\left.100 \mu \mathrm{l}\right)$, the cells that migrated out onto the lower surface of membranes were fixed in $4 \%$ paraformaldehyde. These cells were stained with $1 \%$ crystal violet and counted.

Data analysis. All experiments were completed at least in triplicates, and the data were presented as Mean \pm SD. For statistical analysis, we used a twotailed Student's $t$-test for unequal variances, and the difference between groups was suggested to be significant at $P<0.05$.

\section{Results and Discussion}

Through the control of intercellular communication, EVs of endosomal and plasma membrane origin produced by cancer cells are involved in a plethora of processes related to cancer progression including migration, invasion, angiogenesis, immune response, and chemoresistance [1, 2]. Available experimental data have shown that the content and regulatory potential of EVs secreted by tumor cells depend on the cell of origin [3-5]. In order to establish the biological role of adaptor protein Ruk/CIN85 in the biogenesis of EVs and to study the effect of EVs produced by tumor cells with different levels of adaptor protein expression on in vitro biological responses of target cells, we used previously established sublines of murine breast adenocarcinoma cells with overexpression (4T1 RukUp) and suppressed expression (4T1 RukDown) of Ruk/CIN85. Previously, it was found that 4T1 RukUp cells were characterized by increased malignancy phenotype while 4T1 RukDown cells acquired more benign epithelial phenotype. As a model of target cells, we used 4T1 WT cells.

The number and size of nanoparticles in the selected preparations of EVs produced by Mock, RukUp and RukDown 4T1 cells were assessed by NTA. It was found that the largest number of particles with a relatively large average size produced 4T1 RukUp cells and, conversely, the opposite results were obtained for 4T1 RukDown cells (Table). Interestingly, the number of circulating EVs in breast cancer patients is associated with desease progression and poor prognosis [18], which is consistent with the data obtained.

Visual images of the data obtained with the NanoSight device are presented in Fig. 1, A, typical electron microscopic images of vesicles (labeled with the marker of extracellular vesicles CD63) - in Fig. 1, $B$, and Western-blot analysis of EVs marker proteins CD81 and CD63 in 4T1 WT cells - in Fig. 1, $C$. Altogether, these results confirm the accuracy of EVs protocol isolation.

As there is no information in the literature on the localization of Ruk/CIN85 in EVs, at the next step we analyzed the content of the studied adaptor in vesicle preparations isolated from $4 \mathrm{~T} 1 \mathrm{WT}, 4 \mathrm{~T} 1$ RukUp and 4T1 RukDown cells by Western blot analysis using polyclonal antibodies to C-terminal region of the protein (Fig. 2). As can be seen from Fig. 2, the content of the full-length Ruk/CIN85 form was not only significantly higher in vesicles produced by 4T1 cells with Ruk/CIN85 overexpression, but they also contained increased content of its multiple molecular forms.

The particles concentration and the average size of EVs according to NanoSight measurements

\begin{tabular}{|l|l|c|}
\hline & \multicolumn{1}{|c|}{ Concentration } & $\begin{array}{c}\text { Average } \\
\text { particle } \\
\text { size, } \mathrm{nm}\end{array}$ \\
\hline 4T1 WT & $\begin{array}{l}8.28 \cdot 10^{10} / \mathrm{ml}+/-8.46 \cdot 10^{9} \\
\text { particles } / \mathrm{ml}\end{array}$ & 158.3 \\
\hline 4T1 Up & $\begin{array}{l}1.30 \cdot 10^{11} / \mathrm{ml}+/-8.82 \cdot 10^{9} \\
\text { particles } / \mathrm{ml}\end{array}$ & 167.8 \\
\hline $\begin{array}{l}\text { 4T1 } \\
\text { Down }\end{array}$ & $\begin{array}{l}7.98 \cdot 10^{10} / \mathrm{ml}+/-9.31 \cdot 10^{9} \\
\text { particles } / \mathrm{ml}\end{array}$ & 125.1 \\
\hline
\end{tabular}


$\boldsymbol{A}$
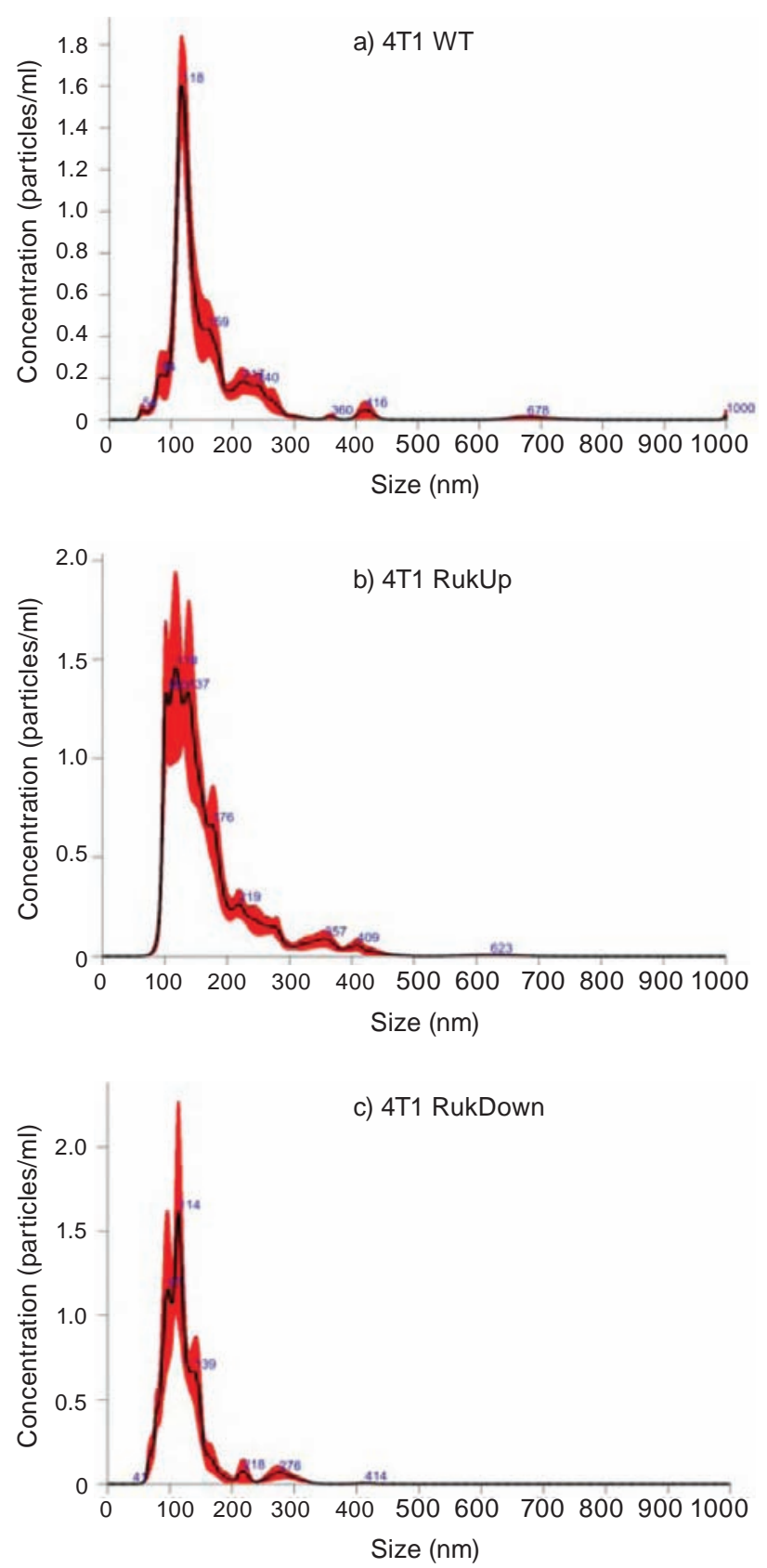

$C$

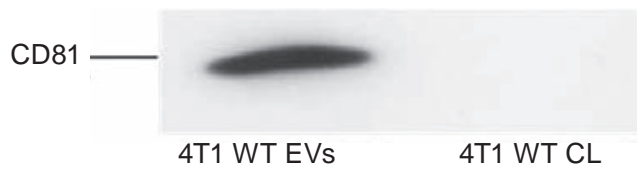

B

a) 4T1 WT EVs

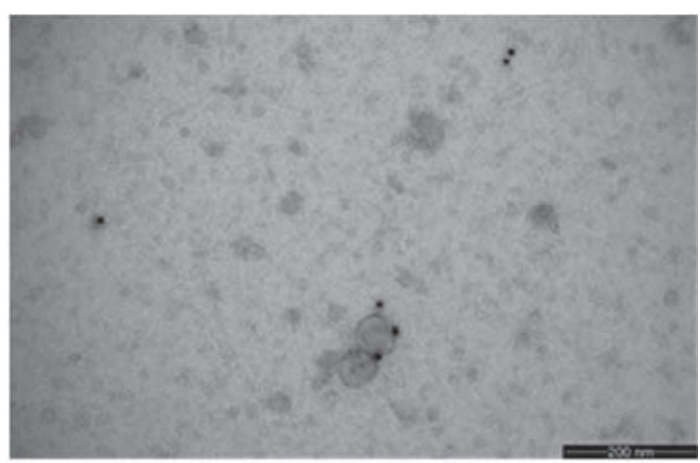

b) 4T1 RukUp EVs

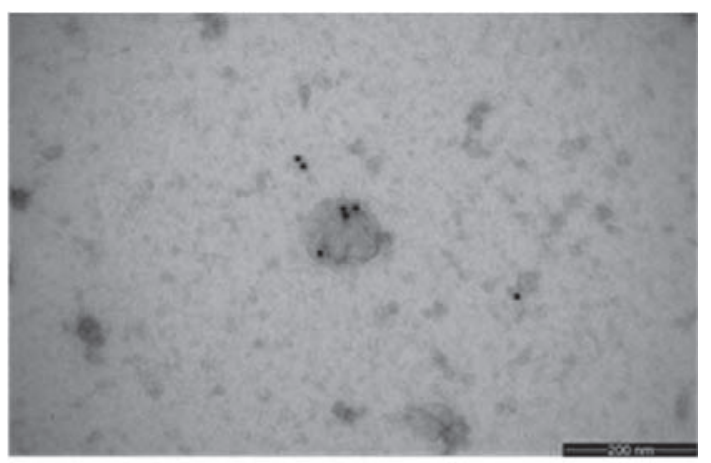

c) 4T1 RukDown EVs
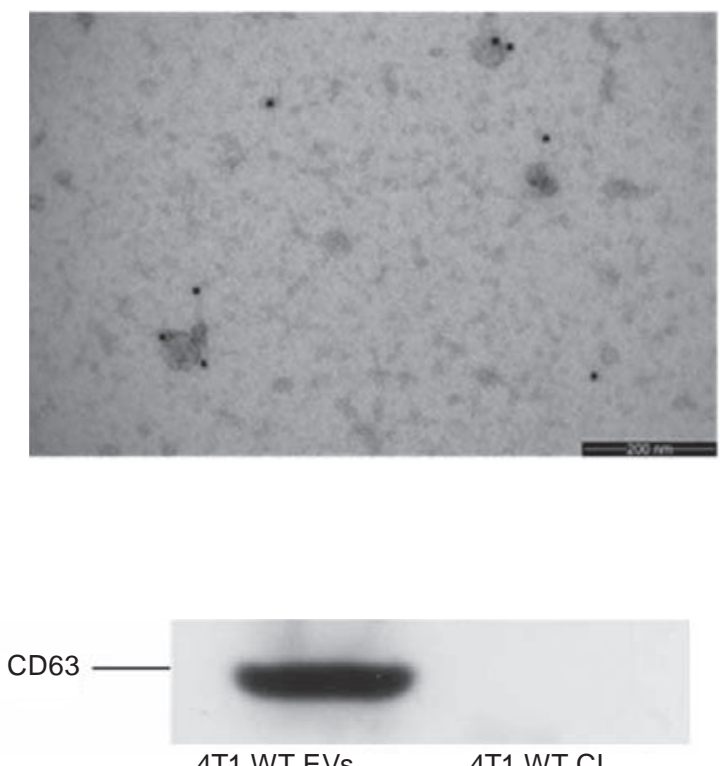

Fig. 1. Isolation and characterization of EVs from $4 T 1$ cells. A. The size distribution of nanoparticles in preparations of EVs isolated from $4 T 1$ cells supernatants via NanoSight measurements. B. Typical electron microscopic images of EVs isolated from $4 T 1$ cells. C. The content of EVs markers, CD81 and CD63 proteins, in EVs preparations and total cell lysates (CL) of $4 T 1$ WT cells 


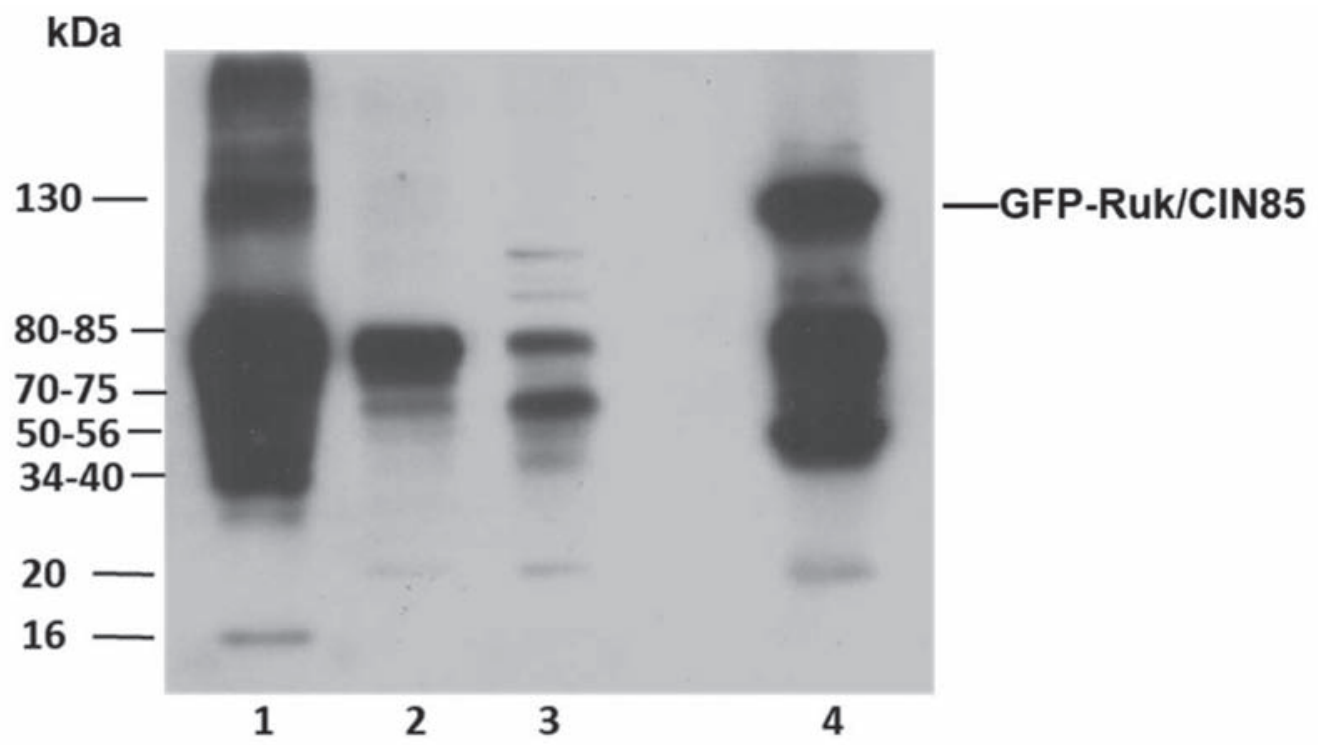

Fig. 2. Extracellular vesicles isolated from $4 T 1$ cells with different levels of Ruk/CIN85 expression are characterized by specific profiles of the content of its multiple molecular forms. 1 - 4T1 RukUp EVs; $2-4 T 1$ WT EVs; 3 - 4 TI RukDown EVs; 4 - lysate of HEK293 cells with overexpression of GFP-Ruk/CIN85. Polyclonal C-terminal anti-Ruk antibodies were used for immunoblot analysis

According to published experimental data, multiple molecular forms of Ruk/CIN85, which are identified by immunoblot analysis using C-terminal antibodies, may be the result of alternative splicing of pre-mRNA (85 kDa - full-length form, $70 \mathrm{kDa}-$ form without the first $\mathrm{SH} 3$ domain, $56 \mathrm{kDa}-$ form without two SH3 domains) [19], post-translational modification by ubiquitilation (130 kDa) [20], and limited proteolysis caused by the presence of PEST motifs sensitive to the action of proteases that are localized in the C-terminal half of the polypeptide chain $(34-40,20,16 \mathrm{kDa})$ [21]. The presence of multiple sites for Ser/Thr-specific protein kinases in the Ruk/CIN85 structure suggests that the subforms around these molecular weights are mainly the result of post-translational modification of Ruk/CIN85 isoforms by phosphorylation. Typically, the modified proteins have lower electrophoretic mobility during SDS PAGE electrophoresis. It was found that extracellular vesicles from 4T1 WT cells are characterized by a much smaller content of full-length form compared to those isolated from 4T1 RukUp cells, but larger compared to 4T1 RukDown cells. Interestingly, we observed the higher content of the form with a molecular weight of about $70 \mathrm{kDa}$ in vesicles from 4T1 RukDown cells compared to those from 4T1 WT cells. Because Ruk/CIN85 is an adaptor/ scaffold protein, the main function of which is to assemble supramolecular complexes in the frame of structural-functional network of cell regulatory mechanisms, differential control of both the content and pattern of its individual molecular forms in EVs may be crucial in intercellular communication and influence of EVs on biological responses of target cells.

At the next step, we analyzed the effect of EVs produced by 4T1 cells with up- and down-regulation of Ruk/CIN85 on the viability, migration, and invasive potential of wild-type 4T1 cells in vitro. The effect of isolated vesicles on the viability of wildtype cells was analyzed using the MTT test (Fig. 3) that reflects the activity of electron transport chain in mitochondria. As turned out, the viability of 4T1 WT cells was found to correlatee negatively with the level of Ruk/CIN85 expression in the sublines from which the extracellular vesicles were isolated. The revealed peculiarities of EVs effects on proliferation rate of 4T1 WT cells may be related to the increased cancer stem features in RukUp cells and vice versa - decreased in RukDown cells [15]. In addition, a metabolic switch from oxidative phosphorylation to glycolysis, known as the Warburg effect [22], was identified to be characteristic of 4T1 RukUp cells and reversed in RukDown cells (our unpublished data).

The effect of isolated EVs on the motility of wild-type 4T1 cells was assessed by scratch assay in the cell monolayer in vitro (Fig. 4, A, B). It was 


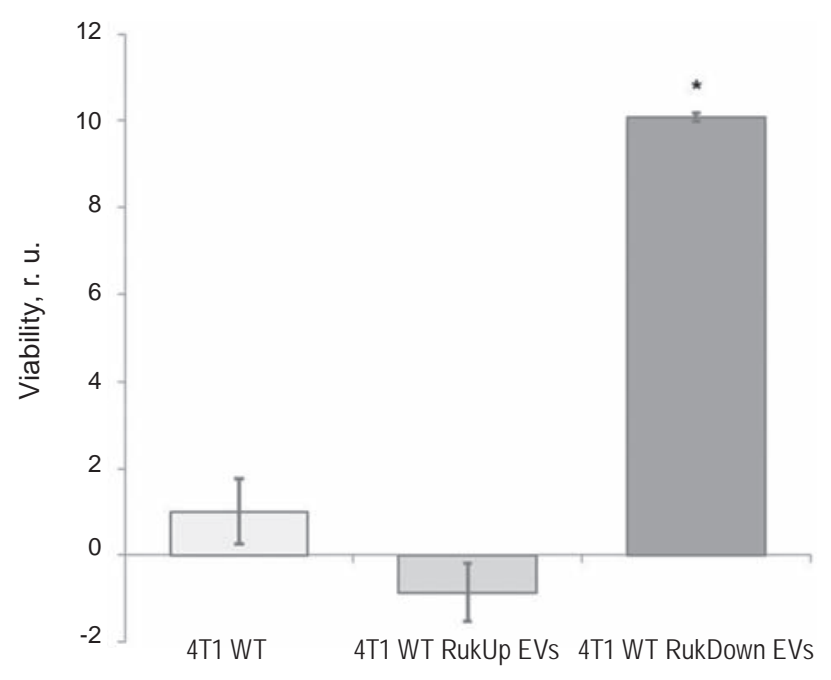

Fig. 3. EVS isolated from $4 T 1$ cells with different levels of Ruk/CIN85 expression modulate the viability of wild-type 4T1 cells in a cell of origin dependent manner. ${ }^{*} P<0.05$ in comparison to $4 T 1$ WT group

found that under the influence of 4T1 RukUp EVs the migration rate of $4 \mathrm{~T} 1 \mathrm{WT}$ cells was almost doubled compared to the control (Fig. 4, B), while under the influence of 4T1 RukDown EVs there was almost complete suppression of their migration potential. Interestingly, in the presence of RukUp EVs, 4T1 WT cells filled the "scratch" with an uneven front, while in the presence of RukDown EVs there was a tendency to fill it with a continuous front, which correlates with increased/suppressed migration features of 4T1 RukUp/RukDown subclones.

The effect of isolated vesicles on the invasiveness of wild-type 4T1 cells was investigated using a modified Boyden chamber with a membrane covered with a Matrigel layer (Fig. 5). The results showed that vesicles isolated from 4T1 cells with Ruk/CIN85 overexpression doubled the invasiveness of wildtype cells, whereas in the presence of RukDown EVs the opposite insignificant tendency was observed (inhibition by about 17\%). Thus, the effects of EVs on the invasiveness of 4T1 WT cells corresponded to the biological properties of highly invasive RukUp and weakly invasive Ruk Down sublines from which they were isolated.

Based on the results of our research, the following conclusions can be drawn:

- The adaptor protein Ruk/CIN85 has been shown to be a newly identified component of EVs produced by breast adenocarcinoma cells that can be used as potential diagnostic marker in breast cancer.
- EVs produced by $4 \mathrm{~T} 1$ cells with different levels of Ruk/CIN85 expression are characterized by subline-specific profiles of the content of its multiple molecular forms.

- The ability of EVs with different content of multiple molecular Ruk/CIN85 forms to modulate the proliferation activity, motility, and invasiveness of wild-type 4T1 cells in vitro correlates with the biological properties of $4 \mathrm{~T} 1$ cells with up- and downregulation of the studied adaptor.

Conflict of interest. Authors have completed the Unified Conflicts of Interest form at http://ukrbiochemjournal.org/wp-content/uploads/2018/12/ coi_disclosure.pdf and declare no conflict of interest.

Funding. The present study was partially supported by the National Academy of Sciences of Ukraine for R\&D "Biochemical mechanisms of control of systemic intercellular interactions, regulation of signaling networks and cellular functions in normal and pathological conditions" (No 0117U004344).

ПОЗАКЛТТННІ ВЕЗИКУЛИ, ЩО
ПРОДУКУЮТЬСЯ КЛІТИНАМИ
АДЕНОКАРЦИНОМИ ГРУДНОЇ
ЗАЛОЗИ МИШІ ЛІНІЇ 4Т1
З НАДЕКСПРЕСІЕЮ ЧИ
ПРИГНІЧЕНОЮ ЕКСПРЕСІЮ
АДАПТЕРНОГО ПРОТЕЇНУ RUК/
СІN85, МОДУЛЮЮТЬ БІОЛОГІЧНІ
ВІДПОВІДІ КЛІТН 4Т1 ДИКОГО
ТИПУ В ЗАЛЕЖНИЙ ВІД
ПОХОДЖЕННЯ СПОСІБ

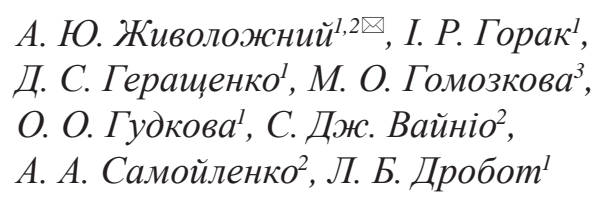

${ }^{1}$ Інститут біохімії ім. О. В. Палладіна НАН України, Київ;

${ }^{2}$ Факультет біохімії та молекулярної медицини, Університет Оулу, Фінляндія; ${ }^{3}$ Університет Брігама Янга Айдахо, Рексбург, США; 凶e-mail: ppndl2@gmail.com

Позаклітинні везикули (ПВ) секретуються більшістю типів клітин як за фізіологічних, так $\mathrm{i}$ за патологічних станів, і активно беруть участь в міжклітинній комунікації. Спосіб дії ПВ залежить від їх вмісту. Під час канцерогенезу вони відіграють важливу роль в ініціюванні пух- 
A

$\mathrm{Oh}$

$24 \mathrm{~h}$
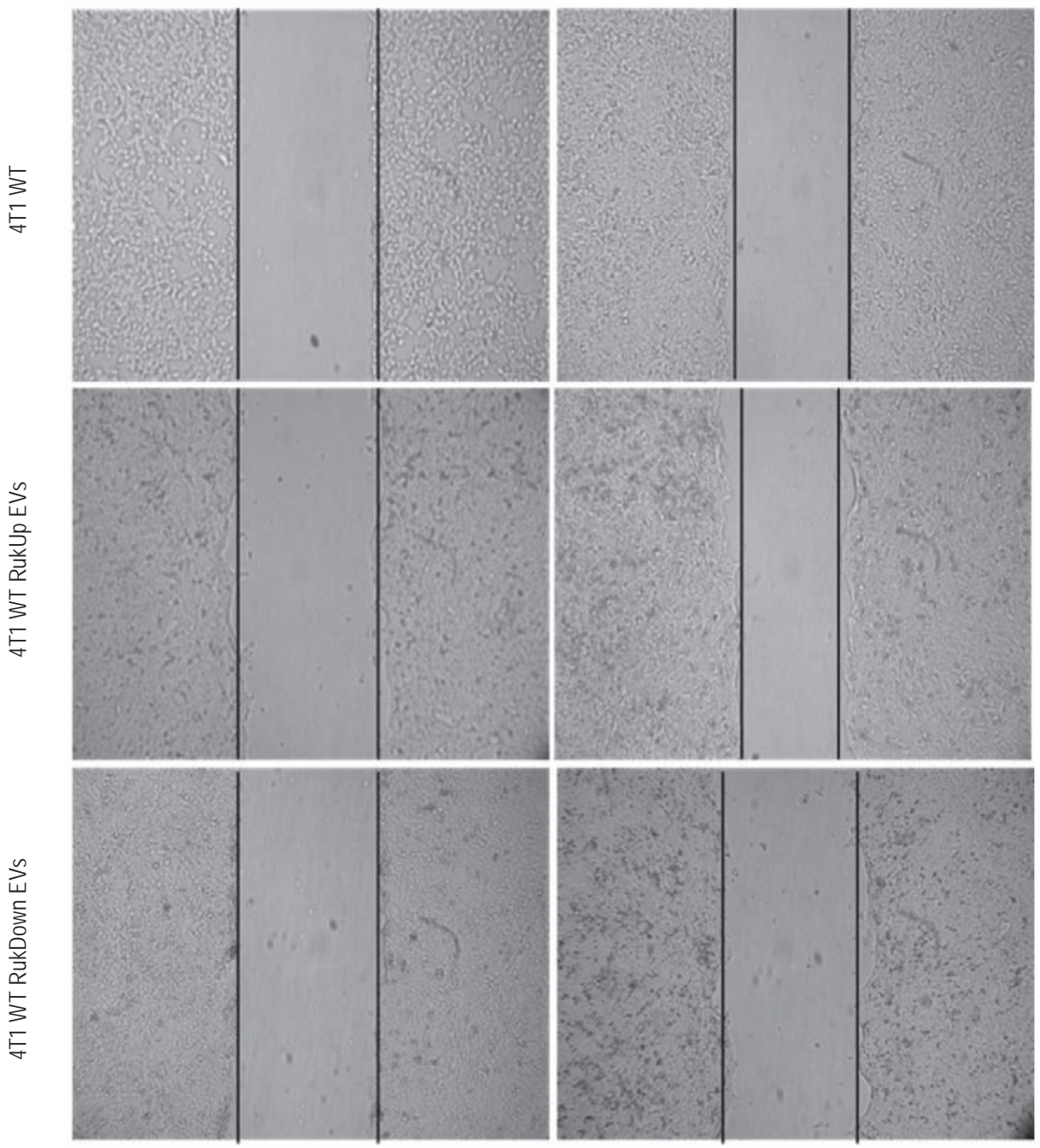

$B$

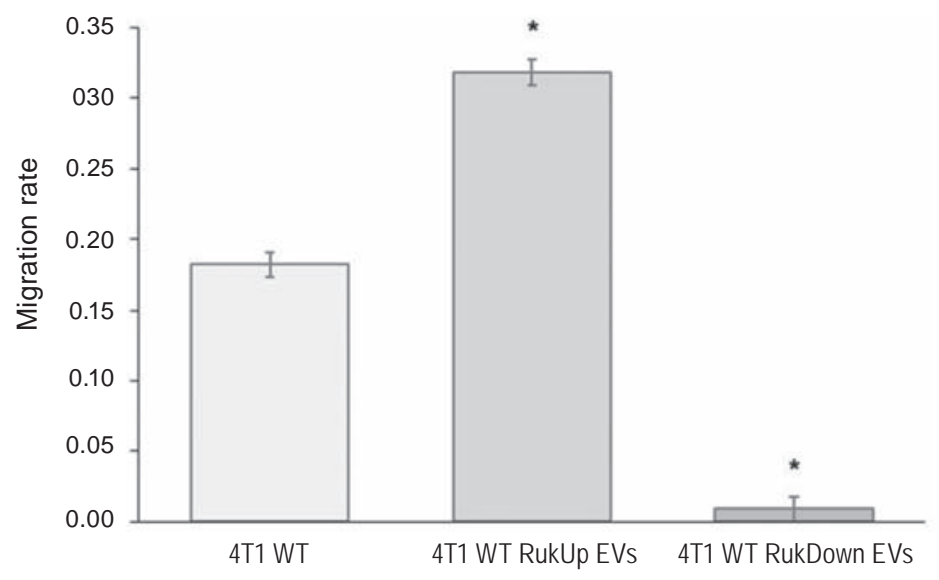

Fig 4. EVs isolated from $4 T 1$ cells with different levels of Ruk/CIN85 expression modulate the motility of wildtype $4 T 1$ cells unidirectionally with the level of their own migration potential. ${ }^{*} \mathrm{P}<0.05$ in comparison to $4 T 1$ WT group 


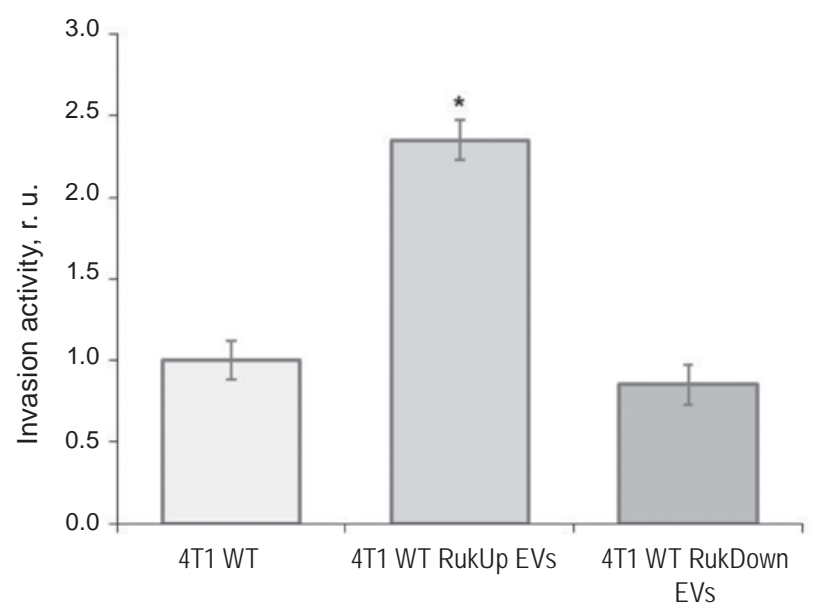

Fig 5. EVs isolated from $4 T 1$ cells with different levels of Ruk/CIN85 expression modulate the invasiveness of wild-type 4T1 cells unidirectionally with the level of their own invasion capability. ${ }^{*} P<0.05$ in comparison to $4 T 1$ WT group

линного росту, рецидивуванні, метастазуванні й розвитку стійкості до терапії. Маркерні протеїни ПВ Alix i Tsg101, залучені до формування мультивезикулярних тілець (MVPs), а також кортактин, що стимулює секрецію ПВ, є зв'язувальними партнерами адаптерного протеїну Ruk/CIN85. Метою цього дослідження було проаналізувати регуляторні ефекти ПВ, що продукуються клітинами 4T1 із надекспресією (RukUp) чи пригніченою експресією (RukDown) адаптерного протеїну Ruk/CIN85 на біологічні відповіді (проліферацію, міграційну та інвазійну активності) вихідних клітин 4T1 WT. ПВ із кондиційованого середовища клітин 4T1 RukUp або RukDown ізолювали шляхом диференційного центрифугування з подальшим очищенням за допомогою набору Exo-spin ${ }^{\mathrm{TM}}$ kit (Cell Guidance Systems). Кількість і розміри ПВ аналізували методом відстеження наночастинок NTA (Malvern Panalytical NanoSight NM300). Вміст маркерних протеїнів i Ruk/ CIN85 в ізольованих ПВ аналізували методом Вестерн-блот аналізу. Життєздатність, рухливість і інвазивність клітин 4T1 WT за дії ПВ досліджували за допомогою МТТ-тесту, тесту на заростання подряпини і модифікованої камери Бойдена, відповідно. Вперше продемонстровано, що адаптерний протеїн Ruk/CIN85 € складовим компонентом ПВ, що продукуються клітинами лінії 4Т1. Також, було показано, що ПВ, які продукуються клітинами 4Т1 з різними рівнями експресії Ruk/CIN85, характеризуються специфічними профілями вмісту множинних молекулярних форм цього протеїну. Встановлено, що здатність ПВ модулювати проліферацію, рухливість і інвазивність клітин 4T1 WT in vitro корелює 3 біологічними властивостями клітин 4Т1, які продукують ПВ (високоінвазивні клітини RukUp або низькоінвазивні клітини RukDown). Одержані дані свідчать про те, що адаптерний протеїн Ruk/CIN85 є не лише складовим компонентом вмісту ПВ, що продукуються аденокарциномними клітинами грудної залози, але й залежно від вмісту в ПВ відіграє активну роль у контролі канцерогенезу.

Кл ю чов і слова: канцерогенез, рак грудної залози, позаклітинні везикули, адаптерний протеїн Ruk/CIN85, життєздатність та міграція клітин, інвазія.

\section{References}

1. Green TM, Alpaugh ML, Barsky SH, Rappa G, Lorico A. Breast Cancer-Derived Extracellular Vesicles: Characterization and Contribution to the Metastatic Phenotype. Biomed Res Int. 2015; 2015: 634865.

2. Peng J, Wang W, Hua S, Liu L. Roles of Extracellular Vesicles in Metastatic Breast Cancer. Breast Cancer (Auckl). 2018; 12: 1178223418767666.

3. Cho JA, Park H, Lim EH, Lee KW. Exosomes from breast cancer cells can convert adipose tissue-derived mesenchymal stem cells into myofibroblast-like cells. Int J Oncol. 2012; 40(1): 130-138.

4. O'Brien K, Rani S, Corcoran C, Wallace R, Hughes L, Friel AM, McDonnell S, Crown J, Radomski MW, O'Driscoll L. Exosomes from triple-negative breast cancer cells can transfer phenotypic traits representing their cells of origin to secondary cells. Eur J Cancer. 2013; 49(8): 1845-1859.

5. Ozawa PMM, Alkhilaiwi F, Cavalli IJ, Malheiros D, de Souza Fonseca Ribeiro EM, Cavalli LR. Extracellular vesicles from triplenegative breast cancer cells promote proliferation and drug resistance in non-tumorigenic breast cells. Breast Cancer Res Treat. 2018; 172(3): 713-723.

6. Pawson T, Nash P. Assembly of cell regulatory systems through protein interaction domains. Science. 2003; 300(5618): 445-452. 
7. Samoylenko A, Vynnytska-Myronovska B, Byts N, Kozlova N, Basaraba O, Pasichnyk G, Palyvoda K, Bobak Ya, Barska M, Mayevska O, Rzhepetsky Yu, Shuvayeva H, Lyzogubov V, Usenko V, Savran V, Volodko N, Buchman V, Kietzmann T, Drobot L. Increased levels of the HER1 adaptor protein Rukl/CIN85 contribute to breast cancer malignancy. Carcinogenesis. 2012; 33(10): 1976-1984.

8. Cascio S, Finn OJ. Complex of MUC1, CIN85 and $\mathrm{Cbl}$ in Colon Cancer Progression and Metastasis. Cancers (Basel). 2015; 7(1): 342-352.

9. Schmidt MHH, Hoeller D, Yu J, Furnari FB, Cavenee WK, Dikic I, Bögler O. Alix/AIP1 antagonizes epidermal growth factor receptor downregulation by the Cbl-SETA/CIN85 complex. Mol Cell Biol. 2004; 24(20): 89818993.

10. Büchse T, Horras N, Lenfert E, Krystal G, Körbel s, Schümann M, Krause E, Mikkat S, Tiedge M. CIN85 interacting proteins in B cellsspecific role for SHIP-1. Mol Cell Proteomics. 2011; 10(10): M110.006239.

11. Lynch DK, Winata SC, Lyons RJ, Hughes WE, Lehrbach GM, Wasinger V, Corthals G, Cordwell S, Daly RJ. A Cortactin-CD2associated protein (CD2AP) complex provides a novel link between epidermal growth factor receptor endocytosis and the actin cytoskeleton. J Biol Chem. 2003; 278(24): 21805-21813.

12. Sinha S, Hoshino D, Hong NH, Kirkbride KC, Grega-Larson NE, Seiki M, Tyska MJ, Weaver AM. Cortactin promotes exosome secretion by controlling branched actin dynamics. J Cell Biol. 2016; 214(2): 197-213.

13. Heppner GH, Miller FR, Shekhar PM. Nontransgenic models of breast cancer. Breast Cancer Res. 2000; 2(5): 331-334.

14. Tao K, Fang M, Alroy J, Sahagian GG. Imagable 4T1 model for the study of late stage breast cancer. BMC Cancer. 2008; 8: 228.

15. Horak IR, Pasichnyk GV, Gerashchenko DS, Knopfova L, Borsig L, Drobot LB. Adaptor protein Ruk/CIN85 modulates manifestation of cancer stem cells (CSCs) features in mouse breast adenocarcinoma 4T1 cells. Dopov Nac akad nauk Ukr. 2018; 12: 101-109.

16. Mayevska $\mathrm{O}$, Shuvayeva $\mathrm{H}$, Igumentseva $\mathrm{N}$, Havrylov S, Basaraba O, Bobak Y, Barska M, Volod'ko N, Baranska J, Buchman V, Drobot L. Expression of adaptor protein Ruk/CIN85 isoforms in cell lines of various tissue origins and human melanoma. Exp Oncol. 2006; 28(4): 275-281.

17. Horak I, Prylutska S, Krysiuk I, Luhovskyi S, Hrabovsky O, Tverdokhleb N, Franskevych D, Rumiantsev D, Senenko A, Evstigneev M, Drobot L, Matyshevska O, Ritter U, Piosik J, Prylutskyy Yu. Nanocomplex of Berberine with C60 Fullerene Is a Potent Suppressor of Lewis Lung Carcinoma Cells Invasion In Vitro and Metastatic Activity In Vivo. Materials (Basel). 2021; 14(20): 6114.

18. Galindo-Hernandez O, Villegas-Comonfort S, Candanedo F, González-Vázquez MC, ChavezOcaña S, Jimenez-Villanueva $X$, SierraMartinez M, Salazar EP. Elevated concentration of microvesicles isolated from peripheral blood in breast cancer patients. Arch Med Res. 2013; 44(3): 208-214.

19. Buchman VL, Luke C, Borthwick EB, Gout I, Ninkina N. Organization of the mouse Ruk locus and expression of isoforms in mouse tissues. Gene. 2002; 295(1): 13-17.

20. Verdier F, Valovka T, Zhyvoloup A, Drobot LB, Buchman V, Waterfield M, Gout I. Ruk is ubiquitinated but not degraded by the proteasome. Eur J Biochem. 2002; 269(14): 3402-3408.

21. Gout I, Middleton G, Adu J, Ninkina NN, Drobot LB, Filonenko V, Matsuka G, Davies AM, Waterfield M, Buchman VL. Negative regulation of PI 3-kinase by Ruk, a novel adaptor protein. EMBO J. 2000; 19(15): 4015-4025.

22. Hu Y, Lu W, Chen G, Wang P, Chen Z, Zhou Y, Ogasawara M, Trachootham D, Feng L, Pelicano H, Chiao PJ, Keating MJ, GarciaManero G, Huang P. K-ras(G12V) transformation leads to mitochondrial dysfunction and a metabolic switch from oxidative phosphorylation to glycolysis. Cell Res. 2012; 22(2): 399-412. 